Jurnal Keperawatan Muhammadiyah

Alamat Website: http://journal.um-surabaya.ac.id/index.php/JKM

\title{
Kajian Hubungan Komponen Beban Kerja Dengan Kinerja Perawat Pelaksana Di Ruang Rawat Inap Rumah Sakit Harapan Bunda Batam
}

\section{Didi Yunaspi ${ }^{1}$, Zulkarnain Edward ${ }^{2}$, Emil Huriani ${ }^{3}$}

${ }^{1}$ Fakultas Keperawatan Universitas Andalas, Padang, Sumatra Barat, Indonesia

2,3 Department Keperawatan, Prodi Ilmu Keperawatan, Ilmu Keperawatan, Fakultas Kedokteran, Universitas Batam

\section{INFORMASI}

Korespondensi: rozaerda21@gmail.com

Keywords:

Workload, Performance, Nurse, Types of nursing activities

\section{ABSTRACT}

In the inpatient room of the Harapan Bunda Batam hospital nurses complained of excessive workloads and the number of nurses that did not match the number of patients who had to be served. High workload will reduce nurse performance. A good nursing performance will create quality implementation of a quality nursing process. The purpose of this study was to determine the relationship of workload components with the performance of implementing nurses in the inpatient room at Harapan Bunda Hospital in Batam. Descriptive analytic research design, "cross sectional" approach. Data collection was carried out from 5 to 17 January 2015 in total sampling. Data was collected by observation and using a questionnaire. Data were analyzed using Chi-Square Test. The results showed the number of patients treated was not in accordance with the number of nurses, the type of nurse nursing activities were productive, the average time for nursing nurses implementing activities was effective, the performance of implementing nurses was good for, there was a significant relationship between the number of patients, types of activities nursing with nurse nurse performance, but there is no significant relationship between the average time of nursing activities with the performance of nursing nurses in the inpatient room of the hospital. Hope Mother. Suggestions for the nursing field that the system of providing professional nursing services in inpatient installations. 


\section{PENDAHULUAN}

Rumah sakit sebagai salah satu fasilitas perayanan kesehatan perorangan merupakan bagian dari sumber daya kesehatan yang sangat diperlukan dalam mendukung penyelenggaraan upaya kesehatan. Penyelenggaran pelayanan kesehatan di rumah sakit mempunyai karakteristik dan organisasi yang sangat kompleks. Berbagai jenis tenaga kesehatan dengan perangkat keilmuan yang beragam, berinteraksi satu sama lain. Ilmu pengetahuan dan teknologi kedokteran yang berkembang sangat pesat yang perlu diikuti oleh tenaga kesehatan dalam rangka pemberian pelayanan yang bermutu standar, membuat semakin kompleksnya permasalahan di rumah sakit. Pada hakekatnya rumah sakit berfungsi sebagai tempat penyembuhan penyakit dan pemulihan kesehatan. Fungsi dimaksud memiliki makna tanggung jawab yang seyogyanya merupakan tanggung jawab pemerintah dalam meningkatkan taraf keejahteraan masyarakat. (Depkes, 2008)

Perawat merupakan salah satu tenaga kesehatan di rumah sakit memegang peranan penting dalam upaya mencapai tujuan pembangunan kesehatan. Pelayanan kesehatan bergantung pada keberhasilan partisipasi perawat dalam memberikan asuhan keperawatan yang berkualitas bagi pasien (Potter \& Perry, 2005).

Belum dilaksanakannya job description yang sudah dibuat secara maksimal oleh perawat rumah sakit akan berdampak pada hasil penilaian kinerja sebagai bahan evaluasi bagi manajemen rumah sakit. Perlu dilakukan upaya agar perawat mampu melaksanakan tugasnya dengan baik sesuai jobdescription yang sudah ditetapkan. Apabila ini tidak dilakukan maka akan berdampak pada penurunan kualitas kerja serta menurunnya kualitas pelayanan kesehatan yang selama ini sudah cukup baik (Mudayana, 2012)

Hasil penelitian yang dilakukan Tarigan (2011) tentang gambaran kinerja perawat dalam memberikan asuhan keperawatan Rumah Sakit Tk II Putri Hijau Medan diketahui bahwa mayoritas responden memiliki kinerja baik dalam pemberian asuhan keperawatan sebanyak $71 \%$, sedangkan responden yang kinerjanya buruk sebanyak 29\%. Berdasarkan Depkes RI, standar pencapaian kinerja dalam pemberian asuhan keperawatan minimal 75\%. Walaupun hasil penelitian ini menunjukkan $71 \%$ perawat memiliki kinerja baik namun nilai ini belum mencapai standar Depkes RI.

Hasil penelitian Andi, A (2009) tentang FaktorFaktor yang Berhubungan dengan Kinerja Perawat di
Rumah Sakit Umum Daerah (RSUD) Andi Makkasau Parepare Tahun 2009 menunjukkan bahwa sebagian besar responden memiliki kinerja pada kategori baik $(57,5 \%)$ dan kinerja pada kategori kurang (42,5\%) dalam melaksanakan asuhan keperawatan kepada pasien dan keluarganya. Angka pencapaian ini masih sangat rendah dibandingkan dengan standar yang ditetapkan oleh Depkes RI yang memberi syarat angka pencapaian minimal $75 \%$ dalam pemberian Asuhan Keperawatan (Depkes RI, 2004).

Kinerja perawat dipengaruhi beban kerja. Beban kerja berkaitan erat dengan produktifitas tenaga kesehatan, dimana $60,1 \%$ waktu yang benar-benar produktif yang digunakan pelayanan kesehatan langsung dan sisanya 39,9\% digunakan untuk kegiatan penunjang (Ilyas, 2004).

Marquis dan Marquis (2000, dalam Fredna, 2009) mengemukakan beban kerja perawat adalah seluruh kegiatan atau aktivitas yang dilakukan oleh seorang perawat selama bertugas di suatu unit pelayanan keperawatan dalam jangka waktu tertentu. Faktorfaktor yang mempengaruhi beban kerja perawat adalah faktor tenaga perawat, jumlah pasien, keterampilan manajemen perawat atau pengalaman kerja perawat dan pendidikan perawat (Samba, 2000). Menurut Gillies (1994 dalam Liza, S, 2011) Komponen beban kerja perawat terdiri dari jumlah pasien yang datang tiap hari dengan diagnosa dan tingkat penyakit yang berbeda, pengukuran jenis kegiatan keperawatan dan rata-rata waktu untuk kegiatan keperawatan.

Perencanaan yang baik mempertimbangkan : klasifikasi klien berdasarkan tingkat ketergantungan, metode pemberian asuhan keperawatan, jumlah dan kategori tenaga keperawatan serta perhitungan jumlah tenaga keperawatan. Perencanaan kebutuhan tenaga perawat diperlukan utuk mengantisipasi beban kerja perawat (Windy, R. 2008)

Berdasarkan penelitian WHO (1997), beberapa negara di Asia Tenggara termasuk Indonesia ditemukan fakta bahwa perawat yang bekerja di rumah sakit menjalani peningkatan beban kerja dan masih mengalami kekurangan jumlah perawat. Hal ini disebabkan karena keterampilan perawat masih kurang dan kebanyakan perawat dibebani dengan tugas-tugas non keperawatan seperti cleanical work, penyiapan menu makan dan pelayanan farmasi. Beban kerja tersebut semakin dirasakan jika jumlah perawat di suatu unit tidak sesuai dengan beban kerja di unit tersebut (Sukardi, 2005).

Hasil penelitian yang dilakukan International Council 
of Nurses (ICN) menunjukkan, peningkatan beban kerja perawat dari empat pasien jadi enam orang telah mengakibatkan $14 \%$ peningkatkan kematian pasien yang dirawat dalam 30 hari pertama sejak dirawat di rumah sakit. Ini menunjukkan adanya hubungan antara jumlah kematian dengan jumlah perawat per pasien dalam sehari (Rachmawati, 2009).

Berdasarkan hasil penelitian Departemen Kesehatan dan Universitas Indonesia (2005) bahwa terdapat $78,8 \%$ perawat melaksanakan tugas kebersihan, $63,3 \%$ perawat melakukan tugas administrasi dan lebih dari $90 \%$ perawat melaksanakan tugas non keperawatan (misalnya menetapkan diagnosis penyakit, membuat resep dan melakukan tindakan pengobatan) dan hanya 50\% yang melakukan asuhan keperawatan sesuai dengan fungsinya.

Beban kerja perawat yang tinggi akan memberikan dampak terhadap kualitas layanan, terutama dalam meningkatkan kinerja perawat pelaksana. Selain terganggunya kinerja perawat, juga dapat menimbulkan stress pada pekerjaan, kebosanan atau kejenuhan, kelelahan mental, dan menurunnya efektifitas kerja. Adapun dampak psikologis yang dirasakan akibat beban kerja yang tinggi adalah stres, ketegangan dan kebosanan atau kejenuhan dan ada pula perasaan jengkel, wring march atau meningkatnya emosi (Qadarsyah, 2006).

Hasil survey dari PPNI (2006) yang menyatakan bahwa perawat di RS Swasta dengan gaji yang lebih baik ternyata mengalami stres kerja yang lebih besar dibanding perawat di RS Pemerintah yang berpenghasilan lebih rendah.

Rumah Sakit Harapan Bunda Batam merupakan rumah sakit swasta pertama di kota Batam yang berada di tengah-tengah pusat kota yang diharapkan mampu memenuhi keinginan masyarakat dalam pemberian pelayanan kesehatan sesuai dengan visi rumah sakit yaitu menjadikan rumah sakit dengan pelayanan terbaik se Provinsi Kepri di tahun 2017.

Angka Bed Occupancy Rate (BOR) Rumah Sakit Harapan Bunda pada akhir tahun 2013 mencapai angka 70,09 \%, sementara perbandingan jumlah perawat dengan jumlah pasien adalah (1 perawat : 3-5 pasien). Jumlah total perawat dan bidan di rumah sakit Harapan Bunda Batam sebanyak 144 orang yang terdiri dari : ruang rawat inap sebanyak 64 parawat, rawat jalan sebanyak 16 perawat dan 4 bidan, IGD sebanyak 12 perawat, ICU sebanyak 12 perawat, kamar operasi sebanyak 12 perawat dan kamar bersalin sebanyak 12 bidan.
Ruang rawat inap Rumah Sakit Harapan Bunda terdiri dari 4 lantai dengan pembagian ruang rawat berdasarkan kelas dan belum berdasarkan pengelompokkan kasus penyakit. Jumlah tempat tidur yang tersedia di ruang rawat inap sebanyak 115 tempat tidur yang terdistribusi di LT II yang dipimpin oleh 1 orang kepala ruangan 4 orang penanggung jawab shif dan 16 orang perawat pelaksana, di LT III dipimpin oleh 1 orang kepala ruangan, 4 orang penanggung jawab shift dan 12 orang perawat pelaksana, di LT IV dipimpin oleh 1 orang kepala ruangan, 4 orang penanggung jawab shift dan 8 orang perawat pelaksana, di LT V dipimpin oleh 1 orang kepala ruangan, 4 orang penanggung jawab shift dan 8 orang perawat pelaksana.

Hasil studi pendahuluan di ruang rawat inap rumah sakit Harapan Bunda Batam pada tanggal 29 Maret 2014 dengan melakukan observasi 10 format asuhan keperawatan di dalam satus pasien, ditemukan format pendokumentasian keperawatan mulai dari pengkajian sampai evaluasi belum terisi secara lengkap sesuai dengan standar asuhan keperawatan (SAK) yang dimiliki oleh rumah sakit Harapan Bunda.

Hasil wawancara dengan 10 orang perawat pelaksana di ruang rawat inap LT II, III, IV dan V, perawat menyatakan kalau waktu mereka banyak tersita dengan kegiatan-kegiatan yang tidak berhubungan langsung dengan pasien seperti kegiatan-kegiatan tidak langsung dan non keperawatan.

Laporan Bidang keperawatan Rumah Sakit Harapan Bunda tentang keluhan kepala ruangan terhadap anggotanya yang datang terlambat saat masuk dinas dan tidak bisa masuk dinas secara tiba-tiba karena alasan sakit akibat lelah bekerja sehingga pelayanan keperawataan yang seharusnya dimulai dengan jumlah tenaga yang cukup malah tertunda sambil menunggu perawat datang terlambat dan mencari perawat pengganti yang tidak masuk . Laporan ini didukung dengan data dari bagian SDM yang menyatakan angka berobat rawat jalan perawat pelaksana rawat inap rata-rata dalam satu bulan sebanyak 28 orang $(63,7 \%)$ dari total jumlah perawat pelaksana rawat inap sebanyak 44 orang.

Dampak Beban kerja perawat yang tinggi dapat menyebabkan perawat mengalami kelelahan dan kejenuhan yang akan menimbulkan stres kerja pada perawat. Hal tersebut semakin didukung dengan Pengelolaan tenaga kerja yang tidak direncanakan dengan baik sehingga dapat menyebabkan keluhan subyektif, tidak efektif dan tidak efisien yang 
memungkinkan terjadinya ketidakpuasan kerja yang pada akhirnya mengakibatkan turunnya kinerja dan produktivitas serta mutu pelayanan yang merosot (Depkes. RI, 2001).

Berdasarkan hasil penjelasan data-data dan fenomena yang ada peneliti mengambil kesimpulan bahwa perawat yang bekerja di rumah sakit Harapan Bunda Batam cendrung mengalami beban kerja berlebih.

Memperhatikan latar belakang serta adanya masalah pada uraian diatas maka peneliti merasa tertarik dan perlu melakukan penelitian tentang "Kajian Hubungan Komponen Beban Kerja Terhadap Kinerja Perawat Pelaksana di Ruang Rawat Inap Rumah Sakit Harapan Bunda Batam”.

\section{METODE}

Jenis penelitian ini termasuk jenis penelitian Deskritif analitik dengan bentuk rancangan penelitian cross sectional, untuk mengkaji hubungan komponen beban kerja dengan kinerja perawat pelaksana di ruang rawat inap rumah sakit Harapan Bunda Batam. Deskriptif analitik merupakan metode yang bertujuan mendeskripsikan atau memberi gambaran terhadap suatu objek penelitian yang diteliti melalui sampel atau data yang telah terkumpul dan membuat kesimpulan yang berlaku umum (Sugiono, 2009).

Populasi dalam penelitian ini adalah seluruh perawat pelaksana di ruang rawat inap Rumah Sakit Harapan Bunda Batam tahun 2014 yang berjumlah 44 perawat pelaksana.

Sampel adalah sebagian dari populasi yang dipilih (Sugiono, 2007). Teknik pengambilan sampel dalam penelitian ini dilakukan dengan teknik total sampling yaitu seluruh perawat pelaksana di ruang rawat inap rumah sakit Harapan Bunda Batam.

\section{HASIL}

Dari table.1 Didapatkan bahwa semua perawat pelaksana di ruang rawat inap RS. Harapan Bunda Batam dengan kelompok umur dewasa awal (100\%), sebagian besar perawat pelaksana dengan tingkat pendidikan vokasional DIII Keperawatan (84,1\%), dan lebih dari sebagian perawat pelaksana dengan lama bekerja 1-2 tahun (65,9\%).
Tabel.1 Distribusi Frekuensi Responden Berdasarkan Umur, Tingkat Pendidikan dan Lama Bekerja di Ruang Rawat Inap RS. Harapan Bunda Batam Tahun 2014

\begin{tabular}{llcc}
\hline $\begin{array}{c}\text { Karakteris- } \\
\text { tik Perawat }\end{array}$ & \multicolumn{1}{c}{ Kategori } & f & \% \\
\hline Umur & Dewasa awal (18-35 tahun) & 44 & 100 \\
\hline Pendidikan & Vokasional (DIII Kep) & 37 & 84,1 \\
& Profesional (S1 Kep+Ners) & 7 & 15,9 \\
& 1-2 Tahun & 29 & 65,9 \\
\hline Lama & >2-4 Tahun & 14 & 31,8 \\
Bekerja & >4-6 Tahun & 1 & 2,3 \\
\hline
\end{tabular}

Tabel.2Distribusi Frekuensi Jumlah Pasien Yang Dirawat di Ruang Rawat Inap RS. Harapan Bunda BatamTahun 2014

\begin{tabular}{lcc}
\hline \multicolumn{1}{c}{ Jumlah Pasien Yang Dirawat } & f & $\mathbf{\%}$ \\
\hline Sesuai & 7 & 15,9 \\
\hline Tidak Sesuai & 37 & 84,1 \\
\hline Jumlah & 44 & 100 \\
\hline Dari tabel 2 didapatkan bahwa sebagian besar jumlah \\
pasien yang dirawat di ruang rawat inap RS. Harapan \\
Bunda Batam tidak sesuai dengan jumlah perawat \\
yang berdinas $(84,1 \%)$
\end{tabular}

Tabel.3 Distribusi Frekuensi Jenis Kegiatan Keperawatan Perawat Pelaksana di Ruang Rawat Inap RS. Harapan Bunda Batam Tahun 2014

\begin{tabular}{lcc}
\hline \multicolumn{1}{c}{ Jenis Kegiatan Keperawatan } & f & \% \\
\hline Non Produktif & 5 & 11,4 \\
\hline Produktif & 39 & 88,6 \\
\hline Jumlah & 44 & 100 \\
\hline
\end{tabular}

Dari tabel.3 di dapatkan bahwa hampir seluruhnya jenis kegiatan keperawatan perawat pelaksana di ruang rawat inap RS. Harapan Bunda Batam adalah produktif $(88,6 \%)$.

Dari tabel .4 di dapatkan bahwa hampir seluruhnya rata-rata waktu untuk kegiatan keperawatan perawat pelaksana di ruang rawat inap RS. Harapan Bunda Batam adalah efektif (95,5\%). 
Tabel.4 Distribusi Frekuensi Rata-Rata Waktu Untuk Kegiatan Keperawatan Perawat Pelaksana di Ruang Rawat Inap RS. Harapan Bunda Batam Tahun 2014

\begin{tabular}{lcc}
\hline \multicolumn{1}{c}{$\begin{array}{c}\text { Rata-Rata Waktu Untuk Kegiatan } \\
\text { Keperawatan }\end{array}$} & f & \% \\
\hline Lebih dari waktu kerja efektif & 2 & 4,5 \\
\hline Efektif & 42 & 95,5 \\
\hline Jumlah & 44 & 100 \\
\hline
\end{tabular}

Tabel.5Distribusi Frekuensi Kinerja Perawat Pelaksana di Ruang Rawat Inap

RS. Harapan Bunda Batam Tahun 2014

\begin{tabular}{lcc}
\hline \multicolumn{1}{r}{ Kinerja Perawat Pelaksana } & f & \% \\
\hline Baik & 31 & 70,5 \\
\hline Kurang Baik & 13 & 29,5 \\
\hline Jumlah & 44 & 100 \\
\hline
\end{tabular}

Dari Tabel. 5 didapatkan bahwa lebih dari sebagian kinerja perawat pelaksana di ruang rawat inap RS. Harapan Bunda Batam adalah baik (70,5\%)

Tabel.6 Hubungan Jumlah Pasien Yang dirawat Dengan Kinerja Perawat Pelaksana Di Ruang Rawat Inap Rumah Sakit Harapan Bunda BatamTahun 2014

\begin{tabular}{|c|c|c|c|c|c|c|c|}
\hline \multirow{3}{*}{$\begin{array}{c}\text { Jumlah } \\
\text { Pasien Yang } \\
\text { Dirawat }\end{array}$} & \multicolumn{4}{|c|}{$\begin{array}{l}\text { Kinerja Perawat Pelak- } \\
\text { sana }\end{array}$} & \multirow{2}{*}{\multicolumn{2}{|c|}{ Total }} & \multirow{3}{*}{ हृ } \\
\hline & \multicolumn{2}{|c|}{$\begin{array}{c}\text { Kurang } \\
\text { Baik }\end{array}$} & \multicolumn{2}{|c|}{ Baik } & & & \\
\hline & f & $\%$ & f & $\%$ & f & $\%$ & \\
\hline Tidak Sesuai & 8 & 21,6 & 29 & 78,4 & 37 & 100 & 0 \\
\hline Sesuai & 5 & 71,4 & 2 & 28,6 & 7 & 100 & $\Xi$ \\
\hline
\end{tabular}

Dari tabel .6 didapatkan bahwa proporsi kinerja perawat pelaksana lebih baik pada jumlah pasien yang dirawat tidak sesuai dengan jumlah perawat $(78,4 \%)$, dibandingkan jumlah pasien yang dirawat sesuai dengan jumlah perawat $(28,6 \%)$. Hasil uji statistik chi square diperoleh nilai $\mathrm{p}=0,017$, berarti terdapat hubungan yang signifikan antara jumlah pasien yang dirawat dengan kinerja perawat pelaksana.

Dari tabel .7 didapatkan proporsi kinerja perawat pelaksana kurang baik pada jenis kegiatan keperawatan non produktif sebanyak (80,0\%), dibandingkan jenis kegiatan keperawatan produktif (20,0\%). Hasil uji statistik chi square diperoleh nilai $\mathrm{p}=0,022$, berarti terdapat hubungan yang signifikan antara jenis kegiatan keperawatan dengan kinerja perawat pelaksana.

Tabel.7 Hubungan Jenis Kegiatan Keperawatan Dengan Kinerja Perawat Pelaksana Di Ruang Rawat Inap Rumah Sakit Harapan Bunda Batam Tahun 2014

\begin{tabular}{|c|c|c|c|c|c|c|c|}
\hline \multirow{3}{*}{$\begin{array}{c}\text { Jenis } \\
\text { Kegiatan } \\
\text { Keperawatan }\end{array}$} & \multicolumn{4}{|c|}{$\begin{array}{c}\text { Kinerja Perawat } \\
\text { Pelaksana }\end{array}$} & \multirow{2}{*}{\multicolumn{2}{|c|}{ Total }} & \multirow{2}{*}{$\begin{array}{c}\mathbf{p} \\
\text { value }\end{array}$} \\
\hline & \multicolumn{2}{|c|}{$\begin{array}{c}\text { Kurang } \\
\text { Baik }\end{array}$} & \multicolumn{2}{|c|}{ Baik } & & & \\
\hline & f & $\%$ & f & $\%$ & f & $\%$ & \\
\hline Non Produktif & 4 & 80,0 & 1 & 20,0 & 5 & 100 & 0,022 \\
\hline Produktif & 9 & 23,1 & 30 & 76,9 & 39 & 100 & \\
\hline
\end{tabular}

Tabel.8 Hubungan Rata-Rata Waktu Kegiatan Keperawatan Dengan Kinerja Perawat Pelaksana Di Ruang Rawat InapRumah Sakit Harapan BundaBatam Tahun 2014

\begin{tabular}{|c|c|c|c|c|c|c|c|}
\hline \multirow{3}{*}{$\begin{array}{c}\text { Rata-Rata } \\
\text { Waktu Ke- } \\
\text { giatan } \\
\text { Keperawatan }\end{array}$} & \multicolumn{4}{|c|}{$\begin{array}{c}\text { Kinerja Perawat } \\
\text { Pelaksana }\end{array}$} & \multirow{2}{*}{\multicolumn{2}{|c|}{ Total }} & \multirow{2}{*}{$\begin{array}{c}\mathbf{p} \\
\text { value }\end{array}$} \\
\hline & \multicolumn{2}{|c|}{$\begin{array}{c}\text { Kurang } \\
\text { Baik }\end{array}$} & \multicolumn{2}{|c|}{ Baik } & & & \\
\hline & f & $\%$ & f & $\%$ & f & $\%$ & \\
\hline Lebih Dari & 1 & 50,0 & 1 & 50,0 & 2 & 100 & \\
\hline & & & & & & & 0,508 \\
\hline Efektif & 12 & 28,6 & 30 & 71,4 & 42 & 100 & \\
\hline \multicolumn{8}{|c|}{$\begin{array}{l}\text { Dari tabel .8 didapatkan proporsi kinerja perawa } \\
\text { pelaksana lebih baik pada rata-rata waktu kegiatar } \\
\text { keperawatan efektif sebanyak }(71,4 \%) \text {, dibandingkar } \\
\text { rata-rata waktu kegiatan keperawatan lebih dari waktt } \\
\text { kerja efektif sebanyak }(50,0 \%) \text {. Hasil uji statistil } \\
\text { chi square diperoleh nilai p }=0,508 \text {, berarti tidal } \\
\text { terdapat hubungan yang signifikan antara rata-rat } \\
\text { waktu kegiatan keperawatan dengan kinerja perawa } \\
\text { pelaksana. }\end{array}$} \\
\hline
\end{tabular}

\section{PEMBAHASAN}

1. Hubungan Jumlah Pasien Yang dirawat Dengan Kinerja Perawat Pelaksana Di Ruang Rawat Inap Rumah Sakit Harapan Bunda Batam

Hasil penelitian menunjukkan bahwa proporsi kinerja perawat pelaksana lebih baik pada jumlah pasien yang dirawat tidak sesuai dengan jumlah perawat $(78,4 \%)$, dibandingkan jumlah pasien yang dirawat sesuai dengan jumlah perawat $(28,6 \%)$. Hasil uji statistik chi square diperoleh nilai $\mathrm{p}=0,017$, berarti terdapat hubungan yang signifikan antara jumlah pasien yang 
dirawat dengan kinerja perawat pelaksana.

Hasil penelitian ini sesuai dengan penelitian yang dilakukan Werna (2001), bahwa ada hubungan yang signifikan antara jumlah pasien yang dirawat dengan kinerja perawat pelaksana dengan $(p=0,004)$. Dari pengamatan di ruang rawat inap perawat pelaksana memiliki tanggung jawab yang banyak terhadap pasien. Perawat sibuk dengan pelayanan asuhan keperawatan maupun program medis pasien.

Analisis peneliti dalam hal ini disebabkan karena pasien yang jumlahnya sedikit dan tindakan yang dilakukan oleh perawat sebagian besar tidak bervariatif dan tidak membutuhkan waktu yang lama pada masing-masing pasien sehingga perawat pelaksana dapat memberikan tindakan keperawatan dengan tepat terhadap pasien meskipun dari sisi jumlah perawat tidak sesuai dengan jumlah pasien yang dirawat.

2. Hubungan Jenis Kegiatan Keperawatan Dengan Kinerja Perawat Pelaksana Di Ruang Rawat Inap Rumah Sakit Harapan Bunda Batam

Hasil penelitian menunjukkan bahwa proporsi kinerja perawat pelaksana kurang baik pada jenis kegiatan keperawatan non produktif sebanyak (80,0\%), dibandingkan jenis kegiatan keperawatan produktif $(20,0 \%)$. Hasil uji statistik chi square diperoleh nilai $\mathrm{p}=0,022$, berarti terdapat hubungan yang signifikan antara jenis kegiatan keperawatan dengan kinerja perawat pelaksana.

Hasil penelitian ini sama dengan penelitian yang dilakukan Werna (2001) bahwa ada hubungan yang signifikan antara jenis kegiatan dengan kinerja perawat pelaksana dengan $(\mathrm{p}=0,000)$. Observasi diruang rawat inap didapatkan bahwa perawat pelaksana melaksanakan berbagai jenis kegiatan yaitu keperawatan langsung, tidak langsung seperti meyiapkan peralatan dan non keperawatan yang dilakukan berdasarkan tugas masing-masing dalam satu shift dinas

Penelitian ini ditunjang teori yang dikemukakan oleh Gillies (1994) bahwa jenis kegiatan meliputi kegiatan keperawatan langsung yaitu aktivitas yang berhubungan dengan kebutuhan fisik, psikologis dan spritual pasien, kegiatan keperawatan tidak langsung yaitu menyusun rencana perawatan, menyiapkan alat, melakukan konsultasi dengan anggota tim, membaca catatan perawatan, melaporkan kondisi pasein, koordinasi, pengobatan, tingkat aktivitas dan tindaklanjut perawatan.
Hasil penelitian Arthur \& Anderson dalam Tappen (1998) memberikan gambaran pengguna waktu berbagai jenis pelayanan/kegiatan selama 8 jam sehari menunjukkan hasil bahwa $31 \%$ perawat melaksanakan kegiatan perawatan langsung, 45\% kegiatan keperawatan tidak langsung dan 21\% kegiatan pendokumentasian.

3. Hubungan Rata-Rata Waktu Kegiatan Keperawatan Dengan Kinerja Perawat Pelaksana Di Ruang Rawat Inap Rumah Sakit Harapan Bunda

Hasil penelitian menunjukkan bahwa proporsi kinerja perawat pelaksana lebih baik pada rata-rata waktu kegiatan keperawatan efektif sebanyak (71,4\%), dibandingkan rata-rata waktu kegiatan keperawatan lebih dari waktu kerja efektif sebanyak (50,0\%). Hasil uji statistik chi square diperoleh nilai $\mathrm{p}=0,508$, berarti tidak terdapat hubungan yang signifikan antara rata-rata waktu kegiatan keperawatan dengan kinerja perawat pelaksana.

Gillies (1994 dalam Kurniadi. A, 2013) menyatakan waktu yang dibutuhkan untuk kegiatan keperawatan langsung adalah $4 \mathrm{jam} /$ pasien/hari, kegiatan keperawatan tidak langsung $60 \mathrm{menit} /$ pasien/hari dan kegiatan non keperawatan $15 \%$ dari waktu jam kerja tiap shiftnya.

Hasil penelitian ini berbeda dengan penelitian yang dilakukan Werna (2001) bahwa ada hubungan yang signifikan antara rata-rata waktu kegiatan dengan kinerja perawat pelaksana dengan $(\mathrm{p}=0,002)$. Hasil observasi di ruangan secara langsung rata-rata waktu yang digunakan belum sesuai dengan jenis kegiatan, hal ini karena kategori pasien yang dirawat di ruang rawat belum berdasarkan bangsal akan tetapi berdasarkan kelas perawatan yang mengakibatkan fokus kegiatan keperawatan yang dilakukan bersifat general dimasing-masing lantai rawat inap.

Analisis peneliti perawat pelaksana di ruang rawat inap belum menggunakan waktu yang sesuai berdasarkan jenis kegiatan dan tingkat ketergantungan pasien dan perawat pelaksana lebih dominan dalam menegakkan diagnosa dan melakukan implementasi keperawatan langsung dan tidak langsung dibandingkan melakukan pengkajian, menyusun rencana tindakan dan evaluasi keperawatan sebagai wujud pemenuhan kebutuhan dasar pasien. Kondisi ini di dukung dengan karakteristik pendidikan perawat pelaksana sebagian besar adalah DIII keperawatan (perawat vokasional) dimana berperan dalam melaksanakan tindakan dalam asuhan keperawatan serta terjadinya 
fluktuasi jumlah pasien yang mengalami penurunan pada saat penelitian sehingga waktu yang digunakan kurang optimal.

\section{KESIMPULAN}

1. Sebagian besar jumlah pasien yang dirawat di ruang rawat inap RS. Harapan Bunda Batam tidak sesuai dengan jumlah perawat yang berdinas

2. Hampir seluruhnya jenis kegiatan keperawatan perawat pelaksana di ruang rawat inap RS. Harapan Bunda Batam adalah produktif

3. Hampir seluruhnya rata-rata waktu untuk kegiatan keperawatan perawat pelaksana di ruang rawat inap RS. Harapan Bunda Batam adalah efektif

4. Lebih dari sebagian kinerja perawat pelaksana di ruang rawat inap RS. Harapan Bunda Batam adalah baik

5. Terdapat hubungan yang signifikan antara jumlah pasien yang dirawat dengan kinerja perawat pelaksana di ruang rawat inap RS. Harapan Bunda Batam

6. Terdapat hubungan yang signifikan antara jenis kegiatan keperawatan dengan kinerja perawat pelaksana di ruang rawat inap RS. Harapan Bunda Batam

7. Tidak terdapat hubungan yang signifikan ratarata waktu kegiatan keperawatan dengan kinerja perawat pelaksana di ruang rawat inap RS. Harapan Bunda Batam

\section{SARAN}

1.Direktur Rumah Sakit

a. Memberikan motivasi dalam bentuk reward kepada perawat pelaksana dalam rangka peningkatan kinerja

b. Memberikan punishment yang sesuai kepada perawat pelaksana yang memiliki kinerja yang kurang baik

2. Bidang Keperawatan

a. Meningkatkan jenjang pendidikan perawat pelaksana dari vokasional menjadi profesional dan rekruitment tenaga profesional

b. Agar diterapkan sistem pemberian pelayanan keperawatan profesional (SP2KP) di instalasi rawat inap

c. Diterapkannya penilaian kinerja secara bertahap (tiap 6 bulan) untuk kebutuhan umpan balik dan pengembangan sumber daya manusia.

3. Perawat

a. Lebih memotivasi diri dalam mempertahankan dan meningkatkan kualitas pemberian asuhan keperawatan.

b. Menerapkan asuhan keperawatan berdasarkan standar.

4. Peneliti Selanjutnya

Hasil penelitian ini sebagai data dasar untuk penelitian selanjutnya yang dapat digunakan untuk meningkatkan kemampuan perawat yang berhubungan dengan beban kerja perawat. Disarankan penelitian berikutnya menggunkan deskriptif analitik dengan pendekatan observasional untuk melihat secara detail tindakan yang dilaksanakan perawat dan menggunakan sampel yang lebih besar pada seluruh perawat ruang rawat inap Rumah Sakit Harapan Bunda Batam.

\section{DAFTAR PUSTAKA}

Aditama. (2003). Manajemen Administrasi Rumah Sakit. Jakarta : UI

Depkes RI (1998). Standar Asuhan Keperawatan. Jakarta : Direktorat Rumah Sakit Umum dan Pendidikan, Direktorat Jenderal Pelayanan Medik

Depkes RI (2001). Petunjuk Pelaksanaan Indikator Mutu Pelayanan Rumah Sakit. Jakarta

Depkes RI (2002). Keputusan Menkes RI No.228/ MENKES/SK/III/2002 tentang Pedoman Penyusunan Standar Pelayanan Minimal Rumah Sakit yang Wajib Dilaksanakan Daerah. Jakarta

Depkes RI (2005). Instrumen Evaluasi Penerapan Standar Asuhan Keperawatan di RS. DepKes RI

Depkes RI (2008). Profil Kesehatan Indonesia. Jakarta : Depkes RI

Ernawati, (2011). Kebutuhan Riil Tenaga Perawat Dengan Metode Workload Indikator Staff Need di Rumah Sakit Umum Negara Bali. UNAIR

Faizin, A \& Winarsih, (2008). Hubungan Tingkat Pendidikan Dan Lama Kerja Perawat Dengan Kinerja Perawat Di RSU Pandan Arang Kabupaten Boyolali. Kartasura. UMS

Fredna. (2009). Analisis Beban Kerja Perawat Pelaksana Dalam Mengevaluasi Kebutuhan Tenaga Perawat Di Ruang Rawat Inap Rumah Sakit Umum Prof. dr. R. D. Kandau Manado. Depok : FIKUI

Gaudine. (2000), Measuring nurses' workload, CNA, Publications, nurses Workload march 2003 e.pdf,

Gibson, James L, et.all. (1997). Manajemen. Edisi ke9. Jilid 1. Erlangga, Jakarta. Diterjemahkan oleh 
Zuhad Ichyaudin

Gillies. (1994). Nursing Management : System Approach. (3th ed), philadelpia: W. B. Saunders Co

Hamid, AYS. (2001). Peran Profesi Keperawatan dalam Meningkatkan Tanggung Jawab Perawat Untuk Memberikan Asuhan Keperawatan Profesional Sehubungan Dengan Undang-Undang Konsumen. Jakarta : PPNI

Handoko, T. H. (2001). Manajemen Personalia dan Sumber Daya Manusia. Yogjakarta : BPFE.

Hastono, (2007). Statistik Kesehatan, Jakarta : Raja Grafindo Persada

Heizer dan Render. (2001). Prinsip-prinsip Manajemen Operasi. Jakarta. Salemba Empat

Huber, D.L. (2006). Leadership And Nursing Care Management. $3^{\text {rd }}$ Ed. USA : Elsevier.

Ilyas, Y. (2001). Kinerja Teori Penilaian \& Penelitian. Depok : Pusat Kajian Ekonomi Kesehatan FKM UI

Ilyas, Y (2002). Kinerja : Teori, Penilaian Dan Penelitian. Depok : FKMUI

Ilyas, Y. (2004). Perencanaan SDM Rumah Sakit, Teori, Metoda Dan Formula. Depok : FKMUI

Jauhari. (2005), Analisis kebutuhan tenaga perawat berdasarkan beban kerja di instalasi rawat inap rumah sakit umum. Medan : USU

Kuntoro, A. (2010). Buku Ajar Manajemen Keperawatan. Yogyakarta : Nuha Medika

Kurniadi, A (2013). Manajemen Keperawatan dan Prospektifnya, Jakarta : FKUI

Mangkunegara. (2005). Sumber Daya Manusia perusahaan. Bandung : Remaja Rosdakarya

Magkunegara (2009). Manajemen Sumber Daya Manusia. Bandung : PT. Remaja Rosdakarya

Marquis, B \& Huston. (2000). Ledership Roles and Menegemen Function in Nursing. Philadelphia : Lippincott Company

Mudayana. (2012). Pengaruh Sistim Penilaian Kinerja Dan Keterbukaan Nilai Kinerja Terhadap Motivasi Kerja. Malang : ITNM

Muninjaya, A.G. (1999). Manajemen Kesehatan. Jakarta : EGC

Nawawi, Hadari. (2008). Manajemen Sumber Daya Manusia Untuk Bisnis Yang Kompetitif . Yogyakarta : Gadjah Mada Univesity Press.

Nursalam. (2007). Manajemen Keperawatan Dan Aplikasinya. Jakarta : Salemba Medika

Nursalam (2008). Manajemen Keperawatan Aplikasi dalam Praktik Keperawatan Profesional Edisi
Profesional. Jakarta : Salemba Medika

Nursalam (2008). Konsep dan Penerapan Metodologi Penelitian Ilmu Keperawatan Edisi 2. Jakarta : Salemba Medika

Nursalam (2008). Pendidikan Dalam Keperawatan. Jakarta : Salemba Medika

Nursalam (2011). Manajemen Keperawatan edisi 3.

Jakarta : Salemba Medika

Osok. (1998). Hubungan antara Iklim Kerja dan Motivasi Kerja dengan Waktu produktivitas kerja di Rumah Sakit Islam, Jakarta : FIKUI

Pabundu. (2006). Budaya Organisasi dan Peningkatan Kinerja Perusahaan. Jakarta : Bumi Aksara

Perry \& Potter. (2005). Buku Ajar Fundamental Keperawatan Konsep, Proses, dan Praktik. (Volume I Edisi 4). Jakarta : EGC

Qadarsyah. (2006). Dampak Psikologis Akibat Beban Kerja Pada Perawat di Ruang Rawat Inap TBC Paru Rumah Sakit Paru Batu. Makasar : UMM

Rachmawati. (2009). Manajemen Sumber Daya Manusia. Yogyakarta : CV Andi Offset

Rivai, Veithzal. (2003). Kepemimpinan dan Perilaku Organisasi. Jakarta. PT Rajagrafindo Persada

Mondy, RW, Noe, RM \& Premeaux, RS (1993) Human Resource Management, Fifth Edition, (Massachusetts : A Division of Simon \& Schuster Inc.

Sedarmayanti. (2001). Sumber Daya Manusia dan Produktivitas Kerja. Bandung: Mandar Maju Sedarmayanti. (2007). Manajemen SDM cetakan 1. Bandung : PT. Refika Aditama

Siagian, S (2008). Manajemen Sumber Daya Manusia (cetakan 15). Jakarta: Bumi Aksara.

Suroso. (2011). Hubungan Persepsi Tentang Jenjang Karir Dengan Kepuasan Kerja Dan Kinerja Perawat RSUD Banyumas. Depok : FIKUI

Sukardi. (2005). Metodologi Penelitian Pendidikan : Kompetensi dan Praktiknya. Jakarta : PT Bumi Akasara

Sunyoto, Agus. (1999). Modul Manajemen Sumber Daya Manusia. Jakarta: IPWI

Tarigan. (2011). Gambaran Kinerja Perawat Dalam Memberikan asuhan Keperawatan di Rumah Sakit Putri Hijau. Medan : USU

Terry, George R. (2010). Dasar-dasar Manajemen. Jakarta : Bumi Aksara

Werna. (2001). Hubungan Beban Kerja Dengan Kinerja Perawat Pelaksana Di Ruang rawat Inap Medikal Bedah RSU Labuang Baji Makasar. 
Depok : FIKUI

Wiranata, E. (2013). Hubungan Antara Lama Kerja Dengan Kinerja Perawat Di Instalasi Rawat Inap RSUD Wates. Yogyakarta : UNRIYO

Windy, R. (2007). Hubungan karakteristik pasien dan lingkungan dengan kepuasan pasien terhadap pelayanan keperawatan di Rumah Sakit Islam Sukapura. Jakarta : FIKUI

Yulistiana, R. (2011). Hubungan Komunikasi Organisasi dengan Kinerja Perawat Pelaksana Di Ruang Rawat Inap Rumah Sakit Swasta Surabaya. Depok : FIKUI

Yulmawati. (2011). Efektivitas Kerja Perawat Di Instalasi Rawat Inap Rumah Sakit Umum Mayjen H.A. Thalib Kerinci. Padang : Unand 